\title{
Principals' utilization of external stakeholders in entrepreneurship education - Evidence from the general education
}

\author{
Minna Hämäläinen ${ }^{\text {a1 }}$, Elena Ruskovaara ${ }^{a}$, Timo Pihkala ${ }^{a}$ \\ ${ }^{a}$ Lappeenranta University of Technology
}

\begin{abstract}
The purpose of this article is to examine the principals' networking activities in entrepreneurship education. In this study, we are interested in the principals' actions, when they aim at developing entrepreneurship education in their schools. More precisely, the focus is on how principals utilize external stakeholders in the school context. Our motivation for conducting this study is based on the assumption that while there are external stakeholders supporting entrepreneurship education, principals and their schools are not fully utilizing them. We suggest that the use of external stakeholders may be related to the personal characteristics of the principals, and therefore we examine if or how the background characteristics of the principals explain their use of external stakeholders. Furthermore, we aim at understanding how principals' participation in entrepreneurship education related training explains the level of use of external stakeholders. As a method, analysis of variance and a linear regression analysis are used. The sample consists of 173 Finnish principals working in general education ${ }^{2}$. This article contributes to entrepreneurship education literature by analysis of external network resources in entrepreneurship education. We also pinpoint the role of the principal in this process. The article also provides empirical evidence on the importance of principals' training for utilizing external stakeholders in entrepreneurship education.
\end{abstract}

Keywords: entrepreneurship education, principal, external stakeholders, developing schools

School of Business and Management, Lappeenranta University of Technology (LUT), P.O. Box 20, FI-53851 Lappeenranta, Finland; Minna.Hamalainen@lut.fi

2 In Finland, general education refers to primary and upper secondary education, where students normally are from 7 to 18 years old. 


\section{Introduction}

Entrepreneurship education has gained ground in the European education system. EU's Entrepreneurship 2020 Action plan (European Commission, 2013) defines entrepreneurship as a skill that can be learned, and it highlights the importance of entrepreneurial mindset and skills. The aim is an enterprising, responsible and target-oriented individual, who has the entrepreneurial skills, knowledge and attitudes. Furthermore, entrepreneurship is one of the key competences for European citizens (European Parliament and the Council, 2006). The importance of entrepreneurship education for Europe has been justified based on the evidence that entrepreneurial individuals are more employable, and that entrepreneurship education impacts on young people in a way that they are more likely to set up a new company (European Commission, 2013).

Entrepreneurship education is supported and guided in many ways, and according to the latest Eurydice (2016) report, 11 European countries or regions have a specific strategy for schools' entrepreneurship education. Finland has played a leading role in this process, and since 1994, entrepreneurship education has been part of the Finnish national core-curricula (Ministry of Education, 2009). Despite previously mentioned documents and strategies, it seems that networking with external stakeholders is still not effectively utilized.

There are few studies concerning principals and entrepreneurship education (Birdthistle, Hynes, \& Fleming, 2007; Ememe, Ezeh, \& Ekemezie, 2013; Hämäläinen, Ruskovaara, \& Pihkala, 2018; Ruskovaara, Hämäläinen, \& Pihkala, 2016). Further, there are some studies highlighting the possibilities external stakeholders may play in increasing school's entrepreneurship education activities (Deakins, Glancey, Menter, \& Wyper, 2005; Jones \& Iredale, 2010; Matlay, 2009). Based on these, both principals and external stakeholders seem to have a crucial role in schools' entrepreneurship education, but we could not find studies where principals and external stakeholders are studied together. To fill this gap, we aimed at understanding how principals utilize external stakeholders in terms of developing schools and their entrepreneurship education. The research question of this study is "how principals utilize external stakeholders in entrepreneurship education in their schools?"

Earlier studies (Bennett, 2006; Gibb, 2011) have shown that having entrepreneurial experiences has a positive effect on entrepreneurship education. Therefore, we chose to target on studying the principals' background characteristics, and further, if or how the principals' background characteristics explain the use of external stakeholders. By asking this research question, we focused on operational activities of the principal. We suggest that, as an operational manager of the school, the principal has a decisive role determining 
external relationships of the school (Deakins et al., 2005; Ememe et al., 2013; Hämäläinen et al., 2018; Ruskovaara et al., 2016).

Due to the lack of earlier studies, we needed to combine relative different aspects in order to create the propositions. Especially, we utilized studies where teachers and their entrepreneurship education practices have been studied. Therefore, we built on what studies have discovered about teachers when collaborating with external stakeholders.

This study contributes to the existing literature on entrepreneurship education in two ways. We analyzed the use of external stakeholder resources in entrepreneurship education. We also developed new understanding of the role of the principal in this process, and especially the role of the principals' background characteristics.

\section{Stakeholder involvement in entrepreneurship education}

Several studies have shown that the use of external resources has a direct impact on the level of entrepreneurship education in schools (Deakins et al., 2005; Jones \& Iredale, 2010). According to Matlay (2009), external stakeholder involvement in entrepreneurship education is enriching and influential in the ongoing development of the educational system. Furthermore, Pittaway and Hannon (2008) point out that building relations with external stakeholders is a strategic issue for the school, and external stakeholders play a vital role in developing entrepreneurship education within educational institutions. The literature suggests (Dickson, Solomon, \& Weaver, 2008; Jones \& Iredale, 2010) a few routes to making use of external stakeholders in entrepreneurship education. First, a majority of the stakeholders provide useful materials, content, and experiential models for teachers to use in teaching. As such, stakeholders would not take a first-hand role in teaching, but rather they would be a back-office resource for the teacher. Second, through joint activities, some stakeholders could provide teachers and students with first-hand knowledge, experiential knowledge, and tacit understanding of the world outside the formal school. Finally, the external stakeholders may invest time and money to support entrepreneurship education activities in schools. This may take place through special projects, theme days, company visits, and participation in lectures (Bell, Callaghan, Demick, \& Scharf, 2004; Birdthistle et al., 2007; Cooper, Bottomley, \& Gordon, 2004; Dickson et al., 2008; Gibb, 2011; Sommarström, Ruskovaara, \& Pihkala, 2017).

From the point of view of the principal and the school, local entrepreneurs and various non-profit organizations are part of an essential entrepreneurship education network. Networks may include local companies, associations, 
but also national and international initiatives. It seems that the use of these resources has a direct impact on the level of entrepreneurship education in schools (Deakins et al., 2005; Jones \& Iredale, 2010).

As principals are administrative and pedagogical leaders of their school, they affect the school practices in many ways (Hämäläinen et al., 2018). In this context, the principal's capacity to manage the school and the school's organization has been under scrutiny. Although Ballou and Podgursky (1995) could not find a positive relationship between the principal's work experience and their performance, there are other studies showing that real-life practice as an entrepreneur improves ones' competences as an entrepreneurship educator (Gibb, 2011; Ruskovaara, Pihkala, Seikkula-Leino, \& Järvinen, 2015a). Furthermore, Bennett (2006) suggests that working experience in business enterprises and experiences as entrepreneurs are positive factors in how educators implement entrepreneurship education. The benefits of earlier business experience could be seen as a form of social capital, e.g. the gained business networks and contacts, that would lower the threshold for co-operation; the gained familiarity of business language and behavioral patterns that would make the interaction with businesses easier; and the gained understanding of the expectations of the businesses for building win-win relationships and thereby increase stakeholders' interest for co-operation. However, according to Seikkula-Leino (2007) the length of service does not affect teachers' entrepreneurship education practices. It seems that even the few studies available about principals and entrepreneurship education seem to contradict with each other to some extent. However, researchers seem to agree that entrepreneurship related training positively affect teachers' and principals' entrepreneurship education practices (Bennett, 2006; Deakins et al., 2005; Ruskovaara et al., 2016).

In this article we explore the following propositions:

Proposition 1: The stronger the principal's business background is, the more the principal is bound to utilize external stakeholders in his entrepreneurship education. (Bennett, 2006; Gibb, 2011; Ruskovaara \& Pihkala, 2015; Sullivan, 2000)

Proposition 2: The principal's work experience has no effect on the utilization of external stakeholders in his entrepreneurship education. (Ruskovaara \& Pihkala, 2015; Ruskovaara et al., 2016; Seikkula-Leino, 2007)

Proposition 3: Enterprise-related training positively affects the principal's utilization of external stakeholders in entrepreneurship education. (Bennett, 2006; Ruskovaara \& Pihkala, 2013; Ruskovaara et al., 2015a; Ruskovaara et al., 2016) 


\section{Methods}

The data was collected through the Measurement Tool for Entrepreneurship Education (MTEE) in Finland. The tool was built in cooperation with The National Board of Education and a large group of basic and upper secondary education teachers and principals. The reliability and validity of the tool have been secured by tests and re-tests (Ruskovaara, Pihkala, Seikkula-Leino, \& Rytkölä, 2015b). The measurement tool is a full-scale online questionnaire for identifying the operations of entrepreneurship education at a concrete level for teachers and principals (ibid.). Respondents use the tool on a voluntary basis and data is handled anonymously.

For the analysis, we identified 10 different entrepreneurship education external stakeholders. The selection criteria were as follows: 1) The organization is actively participating in the development of entrepreneurship education. 2) The organization provides support, teaching materials, and/or training for teachers or principals. 3) The organization operates free of charge. 4) The organization can be reached in all parts of Finland, and most of its materials can be found on the internet. 5) The organization has operated for a minimum of ten years in the field of entrepreneurship education.

In the analysis, we included four different principal's background characteristics. (Descriptive statistics of these measures can be found in Table 1.) The principal's characteristics include the following measures: 1) Gender - a dichotomous indicator for the sex of the respondent. The indicator is coded in the data as male $=0$; female $=1.2$ ) Business background - a dichotomous indicator of whether the principal has gained experience in business life. The variable is coded as no experience $=0$; business experience $=1.3$ ) Work experience on a scale of $0-10$ years; $11-20 ; 21-30$; more than 30 years. The experience variable refers to the duration of the principal's position in years. 4) Training courses or training days in entrepreneurship education - an indicator depicting the principals' training as the number of any type and length of entrepreneurship education courses or training days (theoretical or skill-based training) in which the principal has participated. On a scale of none $=0$; some training $=1$; many training sessions $=2$. We included gender and school size as control variables in the analysis.

Table 1 illustrates the respondent's profile. Both genders are almost equally represented. Furthermore, the respondents seem to be rather experienced as most of the principals have more than 20 years of work experience. Although a surprising amount of principals have business backgrounds, the respondents' profile seems to accurately represent Finnish principals in general (see Opetushallitus, 2017). 
Table 1. Description of the respondents $(n=173)$

\begin{tabular}{lccc}
\hline & & $\boldsymbol{N}$ & $\%$ \\
\hline Gender & Men & 90 & 52 \\
\hline Business Background & Nomen & 83 & 48 \\
\hline Work Experience & Yes & 93 & 53,8 \\
\hline & $0-10$ years & 80 & 46,2 \\
\hline & $11-20$ years & 61 & 18,4 \\
\hline Participated in EE Training & $21-30$ years & 70 & 40,3 \\
\hline & Over 31 years & 24 & 13,9 \\
\hline No & 63 & 36,4 \\
\hline School Size & Some & 93 & 53,8 \\
\hline & Many & 17 & 9,8 \\
\hline & -100 pupils & 45 & 26,0 \\
\hline & $100-299$ & 65 & 34,6 \\
\hline & $300-499$ & 321 & 18,5 \\
\hline & $500-$ & 31 & 17,9 \\
\hline
\end{tabular}

\section{Results}

In our analysis, we focused on the principals' use of 10 selected Finnish external stakeholders (Table 2). The questionnaire included the question: "Have you utilized the following external stakeholder/s in your teaching during the last six months?" (Yes/No). In Table 2, the share of the use of each partner is depicted. Economic Information Office seems to be the most used partner, whereas only a limited amount of principals have co-operated with INNOSUOMI. Almost half of the principals ( $48.6 \%$ ) have used Economic Information Office's services, whereas 12.7 percent have utilized INNOSUOMI. Also, Finnish 4-H organization (43.4\%) has gained ground, as well as Employment and Economic Development Office (39.3\%). Some 15-20 percent of principals report utilizing municipal or university services. Regional Entrepreneurship Education YES Centre (36.4\%) and Junior Achievement Finland (28.3\%) are organizations which key focus in on entrepreneurship education, whereas other organizations might also support schools within other themes. 
Table 2. Percentages of principals using different stakeholders $(n=173)$

\begin{tabular}{lc}
\hline & $\%$ of principals using \\
\hline Economic Information Office & $48.6 \%$ \\
\hline Finnish 4-H & $43.4 \%$ \\
\hline Employment and Economic Development Office & $39.3 \%$ \\
\hline Regional Entrepreneurship Education YES Centre & $36.4 \%$ \\
\hline Development Centre Opinkirjo & $32.9 \%$ \\
\hline Junior Achievement Finland & $28.3 \%$ \\
\hline The Federation of Finnish Enterprises & $24.3 \%$ \\
\hline Municipal Business Services & $17.3 \%$ \\
\hline University's Unit of Entrepreneurship & $16.2 \%$ \\
\hline INNOSUOMI - Promoting Finnish Innovation & $12.7 \%$ \\
\hline
\end{tabular}

Building on the frequencies of utilizing different external stakeholders, we created a new sum variable, labeled "Stakeholders", to describe the level of the principals' network activity. In terms of the principals' profile regarding the use of external stakeholders, the frequencies varied between 0 and 10 , where the mean was 2.99. Furthermore, Median was 3.00 and Mode 1.00. This tells us, that the typical principal utilizes one of the aforementioned partners, however, there are principals who are more active and therefore the average is around 3.

Table 3 provides interesting insights into the principals' utilization of external stakeholders. First of all, a principal's utilization of external stakeholders is not a gender issue. Further, a principals' business background and work experience produced significant differences in the principals' utilization of stakeholders. That is, principal's tenure produces differences in stakeholders' utilization, and the most active are the ones with 21-30 years of work experience. In terms of the principals' business background, those with previous business experience seem to be more active in networking with external stakeholders. Interestingly, larger schools show higher scores, but the school size does not produce significant differences. Finally, the more the principal has entrepreneurship education related training, the higher he scores in utilizing external stakeholders. 
Table 3. Utilization of external stakeholders compared with principals' characteristics and participation

\begin{tabular}{|c|c|c|c|c|}
\hline & Group & Means & F-value & Sig. \\
\hline \multirow[t]{2}{*}{ Gender } & Male & 2,97 & 0,028 & 0,868 \\
\hline & Female & 3,02 & & \\
\hline \multirow[t]{2}{*}{ Business background } & No & 2,60 & $6,233^{*}$ & 0,013 \\
\hline & Yes & 3,45 & & \\
\hline \multirow[t]{4}{*}{ Work experience } & $0-10$ years & 1,39 & $4,124^{* *}$ & 0,007 \\
\hline & $11-20$ years & 3,02 & & \\
\hline & $21-30$ years & 3,43 & & \\
\hline & $31-$ years & 2,88 & & \\
\hline \multirow[t]{3}{*}{ Participated in EE trainingl } & No & 1,87 & $23,116^{* * *}$ & 0,000 \\
\hline & Some & 3,31 & & \\
\hline & Many & 5,41 & & \\
\hline \multirow[t]{4}{*}{ School size } & -100 pupils & 2,36 & 2,37 & 0,073 \\
\hline & $100-299$ & 3,00 & & \\
\hline & $300-499$ & 3,19 & & \\
\hline & $500-$ & 3,71 & & \\
\hline
\end{tabular}

Note: ${ }^{*}-p<.05 .{ }^{* *}-p<.01 .^{* * *}-p<.001$.

Next, we analyzed how the different principals' background characteristics are able to explain the utilization of external stakeholders. The linear regression analysis (Table 4) shows a moderate level of R-square, 0.274 . It seems that participation in entrepreneurship education courses and the school size receive the only significant betas. In spite of the statistically significant group-level differences in terms of principals' business background and work experience, it seems that they do not contribute to the explanation of the principals' stakeholder utilization. Interestingly, the school size matters; the bigger the school the more the principal uses the external stakeholders. 
Table 4. Regression analysis of utilization of stakeholders

\begin{tabular}{ll}
\hline Variable & Model 1 \\
\hline Constant & -.412 \\
\hline Gender & .525 \\
\hline Business Background & .364 \\
\hline Work Experience & .341 \\
\hline Participated in EE Training & $1.565^{* * *}$ \\
\hline School Size & $.420^{* *}$ \\
\hline R-square & $.274^{* * *}$ \\
\hline
\end{tabular}

Note: ${ }^{*}-p<.05 .^{* *}-p<.01 .{ }^{* *}-p<.001$.

\section{Conclusions}

Our first proposition suggested that: "The stronger the principal's business background is, the more the principal is bound to utilize external stakeholders in his entrepreneurship education". Our analysis suggests that the principals' business background does not contribute to the explanation of the utilizing external stakeholders. In this sense, the first proposition did not gain support. When compared to earlier studies, this result is a bit surprising. Bennett (2006) reported that long-term hands-on experience is positively related to the adoption of enterprise-related practices. However, according to our data, it seems that business experience has no effect when utilizing external stakeholders. Thus, the networking activities are not dependent on the principal's earlier accumulated social capital, but may depend on some other factors. The observed networking activity may e.g. stem from the activity of stakeholders to initiate collaboration with schools despite the challenges vested in the effort.

The second proposition "The principal's work experience has no effect on the utilization of external stakeholders in his entrepreneurship education" gains no support. Therefore, the principal's work experience seems to be an explanatory factor, and there are differences between recently started and experienced principals. Interestingly, the statistics show a curve-linear tendency; the ones with the shortest work experience are the least active and the activity grows until the principal has some thirty years of experience, and then the activity declines again. Pittaway and Hannon (2008) suggested that relationships with external stakeholders are strategic issues for school. Therefore, principals should have a role there. According to our results, the newer principals are less active with stakeholders, however they might have other forums and practices to interact with surrounding companies. At the same time, our results may indicate that 
principals find their strategic role, regarding external stakeholders, only after some years.

Our third proposition suggested that: "Enterprise-related training positively affects principal's utilization of external stakeholders in entrepreneurship education". Principal's training in entrepreneurship education seems to be an effective way of promoting the utilization of stakeholders; therefore, the proposition is supported. Interestingly, the level of co-operation was almost twice as high among the principals who had participated at least in some training, compared to those who had not participated in any entrepreneurship education training.

As a summary, this study contributes to entrepreneurship education literature by bringing new understanding to if or how the principal's background characteristics explain his use of external stakeholders in developing his school's entrepreneurship education. First, our results suggest that a principals' earlier business background does not explain his activity in utilizing different external stakeholders. Second, a principal's work experience is not an explanatory factor either. Third, entrepreneurship education related training seems to be a very effective way when promoting the utilization of external stakeholders. Further, our results show that utilizing the external stakeholder is not dependent on the principals' gender and finally, the bigger the school the more the principal utilizes the partners studied here.

Our results stimulate many questions. For example, as companies and external stakeholders are claimed to have a crucial role in entrepreneurship education (Jones \& Iredale, 2010; Solomon, 2007), how to enable principals to connect with them? As our results show, typically principals utilize one external stakeholder. What are then the best channels, and how to develop the connections? Who should take the initiative? Or is it the case, that the supply and demand have already been met? Further, our results do not show how the principals use the external stakeholders. Therefore, even one stakeholder may have an impactful role in the schools' entrepreneurship education - or have no impact at all. Finally, what would be the ideal amount for utilizing external stakeholders, and what kind of roles are the most potential ones for principals and teachers?

Since collaboration needs the motivation and capabilities of both parties, our study raises the question of; what is the motivation and capabilities of these school stakeholders to cooperate with schools? This would be a very interesting research topic and actually, some studies have been made about these questions (for example Sommarström et al., 2017). However, in our study, all the stakeholders are motivated by cooperating with schools, because it is their original function. Probably the motivation would be different when collaborating with private companies. 
There are studies (Birdthistle et al., 2007; Gibb, 2011) highlighting the need for more resources targeted at entrepreneurship education. That is understandable, but it seems a bit strange that the organizations studied here operate on a voluntary basis and even provide free materials, but they are not utilized more than described earlier in this study. Of course, one may ask whether it is because of supply and demand, or whether the players just do not know how to best collaborate. Anyhow, based on earlier studies (Dickson et al., 2008; Jones \& Iredale, 2010), that looks like a potential area for development.

This study did not focus on the relationship between principals business background and the use of different business contacts in education. However, we suggest that more research is needed to understand the role and impact of the principals' business background in entrepreneurship education. The findings concerning principals' work experience and the importance of enterprise-related training can be useful when, for example, recruiting new principals. In line with this, the results indicate the importance of enterprise-related training for principals and this is a very practical implication of this study.

Principals' training in entrepreneurship education seems to be an effective way of promoting the utilization of network stakeholders. There are various different kinds of trainings for principals regarding leadership, human resources, administration and economy. These are also very important for principals in their tenure. However, there seems to be only a few enterpriserelated trainings especially targeted for principals. Therefore, we suggest, that more enterprise-related training directed and tailored to the needs of principals would be warranted.

More research is needed to understand the role principals play in managing, guiding and supporting entrepreneurship education in their schools. Further, in this study we focused only on the principals' utilization of external stakeholders, but did not touch upon other crucial elements of entrepreneurship education. For example, we did not study what kind of collaboration principals have done with the stakeholders, nor the teachers' point of view. Moreover, it would be interesting to study the school culture and the role principals play in managing or developing the school to meet the aims set for entrepreneurship education.

As in any study there are some limitations. In this study, we examined only external stakeholders operating free of charge. The results could have been different, if the commercial stakeholders or private companies would have been included. However, based on our knowledge, there are not many commercial stakeholders providing entrepreneurship education related services to schools. In addition, the schools' annual budgets are very limited. Therefore, the use of commercial stakeholders' services at schools must be quite rare 
and our approach remains relevant. Furthermore, the data was gathered from only one country and therefore they may not be generalizable internationally. Further, the data was gathered through an online tool and principals used it on a voluntary basis. Although, crucial decision makers have encouraged principals to respond, it may be that the ones having a more positive attitude towards entrepreneurship education are overly represented in the survey. However, we hope the results are of international interest, as there are only very few studies concentrating on a principals' role in entrepreneurship education, and also, to recognize Finland's contribution and long tradition in Europe of embedding entrepreneurship education in schools.

\section{References}

Ballou, D., \& Podgursky, M. (1995). Recruiting smarter teachers. The Journal of Human Resources, 30(2), 326-338. https://doi.org/10.2307/146122

Bell, J., Callaghan, I., Demick, D., \& Scharf, F. (2004). Internationalising entrepreneurship education. Journal of International Entrepreneurship, 2(1-2), 109-124. https://doi.org/10.1023/B:JIEN.0000026908.35126.15

Bennett, R. (2006). Business lecturers' perceptions of the nature of entrepreneurship. International Journal of Entrepreneurial Behavior \& Research, 12(3), 165-188. https://doi.org/10.1108/13552550610667440

Birdthistle, N., Hynes, B., \& Fleming, P. (2007). Enterprise education programmes in secondary schools in Ireland. Education + Training, 49(4), 265-276. https://doi.org/10.1108/00400910710754426

Cooper, S., Bottomley, C., \& Gordon, J. (2004). Stepping out of the classroom and up the ladder of learning: An experiential learning approach to entrepreneurship education. Industry and Higher Education, 18(1), 11-22. https://doi.org/10.5367/000000004773040924

Deakins, D., Glancey, K., Menter, I., \& Wyper, J. (2005). Enterprise education: The role of head teachers. The International Entrepreneurship and Management Journal, 1(2), 241-263. https://doi.org/10.1007/s11365-005-1131-9

Dickson, P. H., Solomon, G. T., \& Weaver, K. M. (2008). Entrepreneurial selection and success: Does education matter? Journal of Small Business and Enterprise Development, 15(2), 239-258. https://doi.org/10.1108/14626000810871655

Ememe, O. N., Ezeh, S. C., \& Ekemezie, C. A. (2013). The role of head-teacher in the development of entrepreneurship education in primary schools. Academic Research International, 4(1), 242-249.

European Commission (2013). Entrepreneurship 2020 Action Plan. COM (2012) 795 Final. Brussels.

European Parliament and the Council (2006). Recommendation of the European Parliament and of the Council of 18 December 2006 on key competences for lifelong learning. Official Journal of the European Union, L394/310.

Eurydice (2016). Entrepreneurship education at school in Europe. Eurydice Report. Luxembourg: Publications Office of the European Union. 
Gibb, A. (2011). Concepts into practice: Meeting the challenge of development of entrepreneurship educators around an innovative paradigm: The case of the International Entrepreneurship Educators' Programme (IEEP). International Journal of Entrepreneurial Behaviour \& Research, 17(2), 146-165. https://doi.org/10.1108/13552551111114914

Hämäläinen, M., Ruskovaara, E., \& Pihkala, T. (2018). Principals promoting entrepreneurship education: The relationships between development activities and school practices. Journal of Entrepreneurship Education, 21(2), 1-19. Retrieved from https://www.abacademies.org/abstract/principals-promoting-entrepreneurshipeducation-the-relationships-between-development-activities-and-schoolpractises-7127.html.

Jones, B., \& Iredale, N. (2010). Enterprise education as pedagogy. Education + Training, 52(1), 7-19. https://doi.org/10.1108/00400911011017654

Matlay, H. (2009). Entrepreneurship education in the UK: A critical analysis of stakeholder involvement and expectations. Journal of Small Business and Enterprise Development, 16(2), 355-368. https://doi.org/10.1108/14626000910956100

Ministry of Education (2009). Guidelines for entrepreneurship education. Publication of the Ministry of Education. Finland 2009:9. Helsinki: University Print.

Opetushallitus (2017). Opettajat ja rehtorit Suomessa 2016. In T. Kumpulainen (Ed.), Raportit ja selvitykset 2017:2. Juvenes Print - Suomen Yliopistopaino Oy.

Pittaway, L., \& Hannon, P. (2008). Institutional strategies for developing enterprise education: A review of some concepts and models. Journal of Small Business and Enterprise Development, 15(1), 202-226.

https://doi.org/10.1108/14626000810850937

Ruskovaara, E., Hämäläinen, M., \& Pihkala, T. (2016). HEAD teachers managing entrepreneurship education - Empirical evidence from general education. Teaching and Teacher Education, 55, 155-164.

https://doi.org/10.1016/j.tate.2016.01.004

Ruskovaara, E., \& Pihkala, T. (2013). Teachers implementing entrepreneurship education: Classroom practices. Education + Training, 55(2), 204-216. https://doi.org/10.1108/00400911311304832

Ruskovaara, E., \& Pihkala, T. (2015). Entrepreneurship education in schools: Empirical evidence on the teacher's role. The Journal of Educational Research, 108(3), 236-249. https://doi.org/10.1080/00220671.2013.878301

Ruskovaara, E., Pihkala, T., Seikkula-Leino, J., \& Järvinen, M. R. (2015a). Broadening the resource base for entrepreneurship education through teachers' networking activities. Teaching and Teacher Education, 47, 62-70.

https://doi.org/10.1016/j.tate.2014.12.008

Ruskovaara, E., Pihkala, T., Seikkula-Leino, J., \& Rytkölä, T. (2015b). Creating a measurement tool for entrepreneurship education: A participatory development approach. In A. Fayolle, P. Kyrö, \& F. Liñán (Eds.), Developing, shaping and growing entrepreneurship (pp. 40-57). Cheltenham: Edward Elgar Publishing. https://doi.org/10.4337/9781784713584.00009

Seikkula-Leino, J. (2007). Opetussuunnitelmauudistus ja yrittäjyyskasvatuksen toteuttaminen. Opetus-ja kulttuuriministeriö. 
Solomon, G. (2007). An examination of entrepreneurship education in the United States. Journal of Small Business and Enterprise Development, 14(2), 168-182. https://doi.org/10.1108/14626000710746637

Sommarström, K., Ruskovaara, E., \& Pihkala, T. (2017). Company visits as an opportunity for entrepreneurial learning. Journal for International Business and Entrepreneurship Development, 10(3), 298-315. https://doi.org/10.1504/JIBED.2017.085505

Sullivan, R. (2000). Entrepreneurial learning and mentoring. International Journal of Entrepreneurial Behavior \& Research, 6(3), 160-175.

https://doi.org/10.1108/13552550010346587 